\title{
'BOUND TO A CORPSE' IN EARLY MODERN DRAMA: A SUPPLEMENT
}

In a recent contribution to this journal, Sam Thompson has discussed the symbolical significance of 'the recurring idea of a living person bound to a corpse' in early modern drama. ${ }^{1}$ In the present note I want to call attention to further instances of this image and briefly indicate how it was made to operate very effectively in one specific dramatic context. In the opening scene of Sir William Killigrew's tragicomedy The Seege of Urbin (1666), Celestina is revealed 'sitting by a Table.., a Scarfe over her head, holding a dagger in her Handkercher', evidently considering suicide as a way out of an arranged marriage:

What noyse was that, or did I dreame? It seem'd my Fathers voice, to hasten me to Church! The dismall thought of that sad sound, frights my Soule, with apprehesion [sic] of approaching misery! -a thousand Images of strange terrors, do in various shapes appeare, and bring all the sad stories I ever heard, of forced Marriage, afresh into my memory! -if I consent to marry him, or do at all comply! the guilt of our ensuing evils will be mine! -My heart shrinks for fear, at these Ideas of such ills to come! that I will try to think my self into the other World. (A1r) ${ }^{2}$

Making repeated use of the 'bound to a corpse' image, both literally and by allusion, Killigrew goes on to complicate Celestina's predicament, confronting her with a number of excruciating dilemmas. If she complies with her father's commands, she will be responsible for her own and her husband's unhappiness. Suicide before marriage, the alternative to 'an Age of misery' (A1v) she momentarily considers, brings her up against the moral law and the existential fear of going 'I know not where!'. Suicide after marriage, however, when she will be her husband's property, 'will invade his Right' (ib.). Although she remains determined not to 'marry that Monster I abhorre' (A2r), Celestina is finally dissuaded from this course of

\footnotetext{
${ }^{1}$ Sam Thompson, 'Bound to a Corpse : a Macabre Emblem in Early Modern Drama', $\underline{N \& Q}, 59$ (2012), 82-6. All further references to this note will be given in the text.

${ }^{2}$ All references to the text of the play in Four New Playes, viz: The Seege of Urbin. Selindra. Love and Friendship. Tragy-Comedies. Pandora. A Comedy. Written by Sr William Killigrew, Vice-Chamberlaine to Her Majesty (Oxford: Printed by Hen: Hall, 1666).
} 
action by her servant and friend Melina. In order to escape the imbraces of that rich rotten Carcas', Celestina (B1r) decides to escape her 'Rugged Fate' (A2v) by donning men's clothes, fleeing Pisa, and (under the assumed name of Florio) volunteering in the army of the Duke of Urbin, whose city is besieged by the Duke of Ferrara eager to force Princess Silviana into a match that will give him the power over her brother's dukedom. A heroic death on the battle-field in a cause resembling her own, Celestina reflects, will provide the opportunity of flying, once and for all, 'that moving Sepulcher at home' and is a fate far preferable to that of being 'buried while I live!' (B1v) -two further allusions to the emblem under consideration.

When Killigrew came to revise several printed copies of his Four New Playes (1666), he expanded the first scene in The Seege of Urbin in an effort to make the hopelessness of Celestina's situation dramatically even more convincing. In the process he reiterated the image in the context of an added dialogue (partly quoted below) between his heroine and her uncompromising father, a character who had not been given any lines in the printed version of the play:

Enter Father:

What, weeping still! is this thy affection? this thy obedience? in returne for my whole heart, and all my fortune setled on thee! thus to reiect the frute of all my Labors, to make thee Riche, greate, and happie,! -was ever such ingratitude before, or so much folly, so persisted in?

Celestina:

Was ever a kinde father so mistaken? to make the child he Loves, the most wretched creature livinge; to bind me to a halfe dead Corps, that we maye rott together! - Oh Sr! strike your Dagger here, and by my cheerefull Death, iudge how my obedience transends your rigour! by welcominge that stroake from your hand, to free me from the miseryes of such a Mariage... ${ }^{3}$

Like Chapman, Marston, Jonson, and other dramatists before him, Killigrew obviously associated the 'idea of a living person bound to a corpse' with all the ills of an unfortunate marriage (Thompson, 82). In The Seege of Urbin, however, this idea is entertained not by a

\footnotetext{
${ }^{3}$ Not counting minor differences in punctuation and phraseology, this addition is almost identical in the four annotated copies of Four New Playes hitherto identified. The present quotation is from the Brotherton and Rosenbach copies: see John Horden and J.P. Vander Motten, 'Five New Playes: Sir William Killigrew's Two Annotated Copies', The Library, 6 ${ }^{\text {th }}$ Series, 11 (1989), 253-71 (262-3). In the Dyce copy, " a half dead Corps" appears as "an half dead Carcasse": see J.P. Vander Motten, "Another Annotated Copy of Sir William Killigrew's Four New Playes (1666)", The Library, 6 ${ }^{\text {th }}$ Series, 8 (1986), 53-8 (55). The recently discovered Guildhall copy has the Brotherton and Rosenbach reading: see J.P. Vander Motten, 'An annotated copy of Sir William Killigrew's The Seege of Urbin (1666)', forthcoming in American Notes and Queries (2013).
} 
vengeful husband or a guilt-ridden wife but by a clear-sighted young woman revolting against misguided parental authority and insisting on the right of self-determination $-\mathrm{a}$ right facilitated by the male habit she will subsequently assume. Despite Melina's misgivings about such a disguise ('how shall we answer at the Resurrection? for our Viragoships?', B1r), Celestina remains romantically dedicated to her new role as a paragon of female fortitude:

Why should not Womens hearts agree with such a strength, as our Arms have to manage this Sword? 'tis only custome, and a tender Education, makes us lesse bold, and active, then the bravest men; -the Amazons we read, have done great things, and my spirit prompts me to an honourable death, before a wretched life, which makes me thus endeavour, to fall worthy a Noble Character, for after times to pitty, -or to praise, and wonder at! (B1v).

The dramatic action in The Seege of Urbin --its love intrigue complicated by the tensions caused by confused identities-- is thus cleverly predicated on the clear establishment of Celestina's motivation, which itself is vitally informed by her fear of becoming 'bound to a corpse'. The concentration of verbal variants of the phrase suggests that it struck a sympathetic chord with the dramatist, who may have derived it from any number of contemporary sources. Perhaps Geffrey Whitney's emblematic interpretation of the Mezentius icon (Thompson, 84) as a representation of parental tyranny inspired him to connect the notion of paternal sway with that of incompatibility of temper. Some prose writers on the institution of marriage had incorporated both elements in their account of the mutual duties of parents and children, without explicitly establishing a causal relationship between them. Pierre Charron's influential work of ethics De la sagesse (1601), translated into English by Samson Lennard, is a case in point. ${ }^{4}$ Others, like John Milton in The Doctrine and Discipline of Divorce (1643), showed no concern with parental abuse of authority as such and merely

\footnotetext{
${ }^{4}$ Of Wisdome. Three Bookes. Written in French by Peter Charron. Translated by Samson Lennard (London, 1608), chapter 46: 'Another saith, That to marry a wise man to a fool, or a fool to a wise man, is to binde the living to the dead, which was the cruellest death invented by Tyrants, to make the living to languish and die by the company of the dead' (175). Further on, in his discussion of 'true fatherly love', Charron also remarked: 'wee condemne the austere, lordlike, and imperious countenance and cariage of those that never looke upon their children, nor speake unto them but with authoritie, will not be called fathers but lords..' (483). Lennard's translation went through at least seven editions by 1670 .
} 
adduced the (by now widespread) cliché in support of the argument that marriage should be based on 'the fit union of...souls':

But that [i.e. the 'fit union'] can never be where no correspondence is of the mind; nay, instead of being one flesh, they will be rather two carcasses chained unnaturally together; or, as it may happen, a living soul to a dead corpse; a punishment too like that inflicted by the tyrant Mezentius, so little worthy to be received as that remedy of loneliness which God meant us...The meaning therefore of these words, "For this cause shall a man leave his father and his mother, and shall cleave to his wife," was first to shew us the dear affection which naturally grows in every not unnatural marriage, even to the leaving of parents or other familiarity whatsoever. (Book II, ch. xvi) $)^{5}$

To a dramatist intent on clarifying his heroine's motivation, writers like Charron and Milton might have furnished clues, both thematical and verbal, for his opening scene, which dramatizes the idea that 'the leaving of parents' could be the consequence of the lack of a 'dear affection' - as well as being precipitated by the 'unnaturall impositions' of an 'inraged Father' (The Seege, B1r). ${ }^{6}$ In a sermon preached 'at a Wedding in Edmonton', William Secker used the image (or a variant of it) as a warning against another type of unbridgeable gap: 'An old man is not a meet help for a young Woman. He that sets a gray head upon green shoulders, hath one foot in the Grave, and another in the Cradle...A young person, is not a meet help for an old woman; raw flesh is but an ill plaister for rotten bones." ${ }^{7}$ Secker's emphasis on the dangers attendant on a disparity in age would have been particularly applicable to the situation of Celestina, who has been promised to an old man. Rhetorically more vigorous in articulating the miseries of 'forced and lovelesse matches' is what Daniel Rogers had to say in a passage highlighting feelings of physical abhorrence:

...what shal it profit a man to have won a wife with, [sic] all other advantage, in whom is no true amiable thing to winne affection? what a sad bondage is it, to be tied for ever to one thou canst not love? An object of disdayne, of hatred, of loathsomnesse, of stinch? a thing, wherin there is no dramme

\footnotetext{
${ }^{5}$ John Milton, English Prose Writings, ed. Henry Morley (London, 1889), 268-69. Citing Charron, Edward Reyner, 'Minister of the Gospel in Lincoln', also emphasized the moral differences by observing that ' $[\mathrm{t}] \mathrm{o}$ marry unequally, as a wise man to a foolish woman; or a vertuous woman to a profane wicked man, is, as one saith, to binde the living to the dead; which was the cruellest Death invented by Tyrants, to make the living languish and die by the company of the dead': Considerations Concerning Marriage, The Honour, Duties, Benefits, Troubles of it (London, 1657), 8. Celestina's scarf in the opening scene would have been a symbol of obedience, in accordance with Reyner's idea that '[t]his subjection of the wife to the husband was the ground of the womans wearing a vail or covering, as a sign she is under the power and Authority of her Husband... and subject to him. Rebekah took a vail and covered her self when she saw Isaac...'(16).

${ }^{6}$ The first scene, both in the printed edition and as subsequently revised, is absent from the manuscript of the play, preserved at the Bodleian Library, MS Rawl. poet. 29.

A Wedding-Ring Fit for the Finger: Or, the salve of Divinity on the sore of Humanity (London, 1658), 45.
} 
of that which is desireable? How wofull a burden were it to have a dead carcasse bound with cordes to thy backe, to go with thee, every where? who thy heart tels thee, thou knowest no one woman or man of an hundred whom thou canst not as well find in thine heart to love, as her? ${ }^{8}$

In having Celestina recoil at the 'thousand Images of strange terrors' and 'all the sad stories... of forced Marriage', (The Seege, A1r), Killigrew seemed to be alluding to the nature and the longevity of the materials on which he had drawn. These might have included such plays as George Wilkins' The Miseries of Inforst Mariage (London, 1607) and the 'verie excellent and delectable comedie' Philotus (Edinburgh, 1612), whose heroine disguises herself in order to escape the embraces of 'an auld dead stock both cald and dry' (B2r); popular ballads like 'The London Damsels fate by unjust Tyrany' (London, 1670-1692?); or indeed real-life stories of upper-class young women pressured into marriage by adamant parents. ${ }^{9}$ But Killigrew had the good sense of connecting his 'sad story' with the graphic horrors inherent in being 'bound to a corpse'. In addition to being a vignette carrying symbolical associations, as in Chapman and Jonson, this image was thus designed to lend plausibility to and help propel the dramatic action of his most deserving play.

\section{J.P. VANDER MOTTEN}

\section{Ghent University}

\footnotetext{
${ }^{8}$ D. R., Matrimoniall Honour: Or, the mutuall Crowne and comfort of godly, loyall, and chaste Marriage (London, 1642), 154-5.

${ }^{9}$ The title-page of Philotus explains: 'Wherein we may perceive the great inconveniences that fall out in the mariage betweene olde age and youth'. The subtitle of 'The London Damsels fate' describes it as 'a Relation of a handsome maid that was lately through the Tyranny of her Parents, forced from her dearest, to one whom she hated..', and the damsel in question is pictured stabbing herself. On cases of filial disobedience in marriage matters, see Antonia Fraser, The Weaker Vessel. Woman's lot in seventeenth-century England (London, 1984), 30-40. On the evolution of marriage arrangements in the propertied classes, see Lawrence Stone, The Family, Sex and Marriage In England 1500-1800 (London, 1977), 178-95.
} 
